\title{
economics-of-security.eu
}

Syed Mansoob Murshed

\section{Threat Perceptions in Europe: Domestic Terrorism and International Crime}

January 2009

Economics of Security Working Paper 2

This publication is an output of EUSECON, a research project supported by the European Commission's Seventh Framework Programme.

European Security Economics

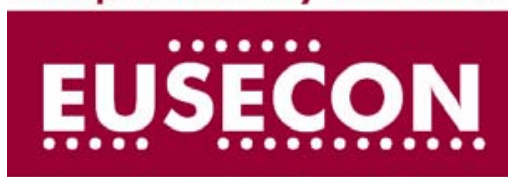

www.economics-of-security.eu

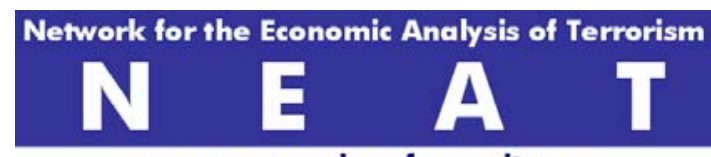

www.economics-of-security.eu 


\section{Economics of Security Working Paper Series}

Correct citation: Murshed, S. M. (2009). "Threat Perceptions in Europe: Domestic Terrorism and International Crime". Economics of Security Working Paper 2, Berlin: Economics of Security.

First published in 2009

(C) Syed Mansoob Murshed 2009

ISSN: $1868-0488$

For further information, please contact:

Economics of Security, c/o Department of International Economics, German Institute for Economic Research (DIW Berlin), Mohrenstr. 58, 10117 Berlin, Germany.

Tel: +49 (0)30 $89789-277$

Email: neat@diw.de

Website: www.economics-of-security.eu 


\title{
THREAT PERCEPTIONS IN EUROPE: DOMESTIC TERRORISM AND INTERNATIONAL CRIME
}

\author{
Syed Mansoob Murshed ${ }^{*}$ \\ Institute of Social Studies (ISS) \\ PO Box 29776 \\ 2502 LT The Hague, The Netherlands \\ The Birmingham Business School \\ University of Birmingham \\ Edgbaston, Birmingham B15 2TT, UK. \\ Centre for the Study of Civil War (CSCW) \\ PRIO, Oslo, Norway \\ Murshed@iss.nl \\ $11^{\text {th }}$ August 2008 \\ Revised: $14^{\text {th }}$ January 2009
}

\begin{abstract}
This paper focuses on two areas of security concern for the European Union: terrorism and international crime. I present a model of game-theoretic interaction between a European state and a domestic dissident group, who, on occasion, may resort to acts of terrorism. Here, identity is crucial to the putative terrorist, providing the microfoundations of dissident group behaviour by solving the collective action problem. I also sketch a macromodel of drugs production in a conflict-ridden developing country, where I argue that demand-side policies of regulation may be better than policies that are aimed at eradicating supply. As far as the policy implications are concerned, first excessive deterrence against potential terrorists may backfire. Secondly, space needs to be created so that Muslim migrants are able to merge their personal identities within their adopted European homelands. Thirdly, the economic discrimination against Muslims in Europe needs to be redressed. Finally, aid to fragile drug producing states should be broad-based and poverty reducing, not just benefiting warlords.
\end{abstract}

Keywords: European Security, Conflict, Terrorism, Narcotics Trade JEL Classification Numbers: C72, D74, D81, F13, F35, H11, O19.

\footnotetext{
* I thank participants of the EUSECON Workshop, Brussels, 23-24 ${ }^{\text {th }}$ September 2008 for their comments on earlier versions.
} 
The purpose of this paper is to focus on two areas of security concern for the European Union; terrorism and international crime. Its focus will be on domestic terrorism and the international trade in illegal narcotic substances. I have analysed transnational terrorism elsewhere, see Addison and Murshed (2005) ${ }^{1}$, and admittedly there are other issues of concern to the European Union, such as refugee influxes from fragile states and the illegal movement of people from poor countries.

Why do the activities of certain minority groups, or elements within them, such as radicalised Islam amongst mainly youthful $2^{\text {nd }}-3^{\text {rd }}$ generation Muslim migrants in various European countries, pose such a threat to the collective security of the European Union? The answer is extreme acts of terrorism such as the Madrid train bombings of March 2004, or the London bombings of July 2005. Besides these acts of violence there are other activities, ranging from inflammatory speeches denouncing the West and the wearing of the hijab (head scarf), that annoy and disturb the majority community in varying degrees throughout Europe. Is this inevitably a result of the clash of civilizations, as outlined by Huntington (1996)? Or are Muslim acts of violence or defiance a product of their deep sense of historic and present-day humiliation, as pointed out by Lindner (2001). These include historical acts such as the wholesale expulsion of Muslims who did not convert to Christianity from Spain (in the $16^{\text {th }}$ and $17^{\text {th }}$ centuries) and from Sicily ( $14^{\text {th }}$ century), as well as during the $20^{\text {th }}$ century in the Middle East, where the British-French Sykes-Picot pact (during the First World War) resulted in an extremely unfair disposition of the former Ottoman territories. Later the emergence of what many regard as a colonial settler state, Israel, and the West's lack of even handed behaviour towards the protagonists in the ArabIsraeli conflict spawned deep resentment, as have growing economic disparities; see Stewart (2008). Other areas of Muslim disadvantage in the recent past include Kashmir in India and Bosnia in the European Balkans. This predicament is often blamed on Western double standards towards the plight of Muslims compared to others. In this connection it has to be mentioned that terrorist acts, such as suicide bombing, may be a rational response if individuals feel a very strong sense of solidarity with their collective sense of humiliation and oppression (Wintrobe, 2002).

More recently, Stewart (2008) has documented the systematic disadvantage that Muslim groups face in European countries and worldwide. These range from economic discrimination in terms of jobs and lower incomes, to the documented negative perceptions amongst the majority (white European) population about the assumed threats to their European way of life and dangers of terrorism posed by Muslim immigrants in their midst. Thus, some of the more extreme forms of terrorism and even other non-violent acts, which make a statement of difference with the majority community such as the wearing of hijabs, may have as their root cause: both the collective sense of injury caused by the sufferings of Muslims globally (such as in Palestine, Iraq or Afghanistan), as well as the more palpable economic, political and social discrimination felt within the European states that they reside in. The latter

\footnotetext{
${ }^{1}$ There we model the three-way interaction between a domestic rebel group (such as al-Qaida), the government they see as oppressive and a Western ally (Saudi Arabia), and a western sponsor of the government (the United States and other Western powers). Deterrence against these putative terrorists, who are rebels in their domestic country could backfire if their resolve is strong.
} 

contemporary Europe. Horizontal inequality is group-based inequality, rather than the inequality in an otherwise culturally or ethnically homogenous society; see Stewart (2000) on this.

Explanations of deviant behaviour based on horizontal inequalities stand in sharp contrast to culturalist explanations that attempt to rationalise the same pattern of behaviour based on the innate nature of Islam, something which is gaining popularity in Europe, judging by the rise in populist parties that espouse the single issue of the dangers posed by Islam, as in Denmark and the Netherlands. Contemporary racism is driven more by cultural identities such as Islam, rather than colour, as in the past. Their ability to influence policy rests with their importance as coalition partners, which is greater in smaller European states with electoral systems that have full proportional representation. In other countries they have greater influence in local politics. According to surveys ${ }^{2}$, negative perceptions about Muslims among nonMuslims have grown in Europe: in 2008 52\% in Spain, 50\% in Germany, 38\% in France and $23 \%$ in the UK felt negative about Muslims. The same survey indicates growth in the Muslim sense of identity amongst Muslims immigrants in Europe, although there is growing aversion to tactics like suicide bombing amongst Muslims in other Muslim countries.

There is a great deal that is said about the 'hatred' felt by a section of immigrant Muslims towards the Western civilization in countries where they reside. What is less well known is the fact that the Islamic religion through its divinely revealed scripture, the Quran, actually celebrates racial diversity ${ }^{3}$ and requires believers to acknowledge earlier Abrahamic Prophets as part of their faith ${ }^{4}$. Some of the sayings of the Prophet Muhammad and his cousin and son-in-law Ali, during Islam's first century (the $7^{\text {th }}$ century AD) are testimony towards inclusiveness. ${ }^{5}$

\footnotetext{
${ }^{2}$ http://pewglobal.org/reports/display.php?ReportID $=262$

3 "O mankind! Lo! We have created you male and female, and have made you nations and tribes that ye may know one another. Lo! the noblest of you, in the sight of Allah, is the best in conduct". Quran: 049.013. Another verse says: "And of His signs is the creation of the heavens and the earth, and the difference of your languages and colours". Quran: 030.022. English translations of the Quran from Marmaduke Pickthall's, The Glorious Quran, http://www.islam101.com/quran/QTP/index.htm

4 "Say (O Muhammad): We believe in Allah and that which is revealed unto us and that which was revealed unto Abraham and Ishmael and Isaac and Jacob and the tribes, and that which was vouchsafed unto Moses and Jesus and the prophets from their Lord. We make no distinction between any of them, and unto Him we have surrendered". Quran: 003.084

${ }^{5}$ Consider an excerpt from Muhammad's Last Sermon as in Baihiqi (circa 632 AD): "O people, Remember that your Lord is One. An Arab has no superiority over a non-Arab nor a non-Arab has any superiority over an Arab; also a black person has no superiority over a white person, nor a white person has any superiority over a black person, except by piety and good action. Indeed the best among you is the one with the best character..... Listen to me. Did I convey this to you properly? People responded, Yes. O messenger of God, The Prophet then said, then each one of you who is there must convey this to everyone not present".

http://www.themodernreligion.com/prophet/prophet_lastsermon.htm

Ali, the 4th Islamic Caliph, also the cousin and son-in-law of Muhammad in a letter to Malik-e-Ashtar, his governor designate to Egypt (circa 656-661 AD): "Remember, Maalik, that amongst your subjects there are two kinds of people: those who have the same religion as you have; they are brothers to you, and those who have religions other than that of yours, they are human beings like you. Men of either category suffer from the same weaknesses and disabilities that human beings are inclined to, they
} 
Another strong threat perception in Europe emanates from organised crime. The increase in transnational crime, particularly associated with the increased drug trade, is widely recognised as part of the negative side of increased globalization. ${ }^{6}$ It is worthwhile noting that the supply of contraband narcotics mainly originates in countries that have experienced civil war. The problems associated with drug production are similar to the causes of conflict, and involve the interaction of greed and grievance within a failing domestic social contract (Murshed, 2002). Poverty produces grievance which can lead to drug production, which results in violence and even more grievance. Armed political groups use drug revenues to finance their wars; alternatively simply to satisfy their greed when the political-economic reasons for war have been assuaged (Northern Ireland). Thus, grievance can easily descend into banditry. Similarly, drug-barons, whose motives are purely mercenary, use armed force to further their political and economic ambitions. ${ }^{7}$

Poverty is as central to the economics of violence as greed. It produces incentives for violent acts, and lowers the costs of fighting. Most drug producing states are lowincome developing countries belonging to the South. Many of the causes of poverty are domestic in nature and are associated with bad policy choices as well as historically inherited inequities in asset ownership. But there are external factors as well. These include the effects of falling commodity prices (coffee, for example), the debt crisis and the poverty increasing effects of macro-stabilisation policies (such as structural adjustment) imposed by multilateral agencies.

The major drug producing nations are Peru, Bolivia and Colombia for coca; Afghanistan, Myanmar and Laos for opium. Many of these countries are characterised by civil war as well as widespread poverty. Most of them have also experienced growth failure. The consumer of drugs is mainly in the developed North, led by the world's only remaining superpower, the USA. In Colombia, where the USA is following a policy of drug eradication at the (farmgate) source of supply, accompanied by a policy of military assistance to the government to fight the drug trade. Colombia is in the midst of a civil war. In Afghanistan, poppy production (the major opium and heroin ingredient) declined, and opium production fell by $90 \%$, following the Taliban government's ban in 2000, see Chossudovsky (2002). Following the US led coalition intervention and the installation of the present government, there has once again been an upsurge in poppy production, and the price of opium in early 2002 was ten times its level in 2000 (Chossudovsky, 2002).

The rest of the paper is organised as follows. Section 2 presents a model of gametheoretic interaction between a European state and a domestic dissident group, who, on occasion, may resort to acts of terrorism. Here, identity is crucial to the putative terrorist; following Akerlof and Kranton (2000), I outline a model where individuals

commit sins, indulge in vices either intentionally or foolishly and unintentionally without realizing the enormity of their deeds. Let your mercy and compassion come to their rescue and help in the same way and to the same extent that you expect Allah to show mercy and forgiveness to you." (Nahjul Balagha) http://www.al-islam.org/nahjul/letters/letter53.htm\#letter53.

${ }^{6}$ According to the UNDCP (1998) estimates, the global production of opium by volume increased by $141 \%$ between $1986-96$. In the same period there was a $24 \%$ rise in coca leaf output.

${ }^{7}$ It has to be admitted that both rebel groups and drug-barons occasionally provide services to the adjoining population. 
Domestic Terrorism and International Crime

Syed Mansoob Murshed derive utility from their identity, identity based actions and the relative social standing of the group that they belong to. This provides the microfoundations of dissident group behaviour by solving the collective action problem. In section 3 I sketch a macro-model of drugs production, based on Murshed (2005), where I argue that demand-side policies of regulation may be better than policies that are aimed at eradicating supply. Finally, section 4 concludes.

\section{TERRORISM}

\subsection{Government $(G)$ :}

The utility of the state or the majority group is given by:

$G=\pi(a, e) G^{P}+(1-\pi)(\cdot) G^{C}-C(a)$

where:

$$
\begin{aligned}
& G^{P}=\bar{Y}^{G}+A-p F^{G}(A, \mu)-T(A) \\
& G^{C}=\bar{Y}^{G}+A-c F^{G}(A, \mu)-\lambda T(A), \lambda<1 \\
& a=\frac{T(A)}{F^{G}(A, \mu)} \\
& c>p>0, c+p=1, \pi_{a, e, t}>0 .
\end{aligned}
$$

For the government, who let us say represent the majority of the voting public, utility is derived from consumption $\left(Y^{G}\right)$ and security expenditure $(A){ }^{8}$ The latter can be used in two ways: a component $\left(F^{G}\right)$ devoted to suppressing (via policing and intelligence surveillance) dissidents, and another element $T$, which is a transfer to the rebel or dissident group, which serves to assuage their grievances. A full and credible transfer only takes place in the peaceful or less polarized state; it is otherwise received with imperfect credibility $(\lambda<1)$ in the state of confrontation. The transfer can mean several things: increased (broad-based) public expenditure, greater inclusion in public sector jobs, political representation and voice in the decision making process. Generally speaking, it is the pecuniary value of including the excluded. Observe that there is a trade-off between suppression (stick) and transfers (carrot).

Note that strategies for the government and rebels are in terms of peaceful behaviour, so $a, e$ raise the chances of peace, $\pi$. $C$ refers to the cost of undertaking $a$ by the state, $C_{a}>0$. These costs consist of the pecuniary and non-pecuniary elements; the first because of the cost of distortionary taxation to finance security, the latter because accommodating dissidents entails a political cost amongst more hawkish constituencies among the majority. The superscripts $P$ and $C$ refer to states which are more peaceful and confrontative, respectively.

\footnotetext{
${ }^{8}$ It can be argued that (1) represents the preferences of a median voter in referenda based democracies, or a similar outcome representing the middle in proportional representation based electoral systems.
} 
The parameter $\mu$ is similar the contest success functions favoured by conflict theorists; see Hirshleifer (1995), for example. Normally, contest success functions in the context of civil war are a ratio of military spending by one side relative to total military expenditure, weighted by decisiveness or a fighting efficiency parameter. Here it has a different interpretation, and represents a set of policies adopted by the government side towards certain minority groups, such as 'radical' Muslims. A higher $\mu$ implies a more confrontative majority that is less inclusive towards certain minorities, and more resolved to combat their dissidence. In equation (2) $G^{P}$ and $G^{C}$ correspond to budget constraints in the two states.

It is instructive to examine the government's strategic variable. Totally differentiating, $a$, the government's strategic choice variable:

$d a=\left[\frac{T_{A}}{F^{G}}-\frac{T}{F_{A}^{G 2}}\right] d A-\frac{T}{F_{\mu}^{G 2}} d \mu$

All the partial derivatives in (3) are positive. The security budget $(A)$ is part of the income of the government, and it can be utilised either to increase transfers to the rebels or fight them. Therein lies a trade-off; thus the term in square brackets in (3) is ambiguous in sign. The second term on the right-hand side of (3) is negative, because a rise in the confrontativeness of the state or majority $(\mu)$ causes it to be less 'peaceful'. For a certain type of government, the first term is positive; it prefers peace. ${ }^{9}$ I utilise this taxonomy, because there may be different expenditure effects following an increase in the security budget depending on the type of government in different countries (or even the same government at different time periods).

Given exogenous payoffs in the two states of peace $(P)$ and conflict $(C)$, the government will maximise (1) with respect to $a$ :

$\pi_{a}\left[G^{P}()-.G^{C}().\right]=C_{a}$

Essentially, this means that the government equates the marginal utility of its strategic action $(a)$ on the left-hand side of (4) to the marginal cost on the right-hand side.

\subsection{Rebels or Dissident $\operatorname{Minorities}(\boldsymbol{R})$ :}

Here we need to distinguish between individual motivation to join a dissident/rebel group and the group dynamics that lead to a clash with the state.

As far as individuals are concerned, following Akerlof and Kranton (2000), I postulate that individuals directly obtain utility from their identity, and the behaviour demanded by that sense of belonging. Thus, a member of a potential minority group

\footnotetext{
${ }^{9}$ Good examples could be given by contrasting the present Spanish and Danish governments. The latter's (or some of its coalition partners) negative attitudes towards Muslims is discernable to the discerning; in sharp contrast, after his election following the Madrid train bombings of 2004, the new Prime Minister of Spain, Zapatero, called a summit of civilizations (including representation from Hamas), as well as instituting an amnesty for illegal immigrants, including Muslim Moroccans who turned out to be the perpetrators of the Madrid train bombings.
} 
Domestic Terrorism and International Crime

Syed Mansoob Murshed (say, Muslims in Europe) derives utility $\left(U_{r}\right)$ in the following manner (where, momentarily, for the sake of analytical tractability I have suppressed consumption:

$U_{r}=U_{r}\left(e_{r}, e_{-r}, I_{r}\right)$

where

$I_{r}=I_{r}\left(e_{r}, e_{-r}, \theta\right)$

The individual derives utility from his own actions $\left(e_{r}\right)$, and from the actions of other like-minded individuals belonging to his group $\left(e_{-r}\right)$, and above all his own identity or self image $\left(I_{r}\right)$, which in turn depends on the actions $\left(e_{r}, e_{-r}\right)$ just described, as well as the inverse of the group's social standing, $\theta$. In other words, the higher is $\theta$, the lower is the group's social standing. ${ }^{10}$ In summary, individuals derive utility from actions conforming to their groups, similar actions by other individuals who also belong to their group, and their own perceived standing in society. Following Akerlof and Kranton (2000) it is also possible to show that individuals derive disutility from the non-conformity of other group members, who do not act or behave in an appropriate manner; see also Gates (2002) on rebel recruitment and retention. Secondly, if the costs of so-doing are sufficiently low compared to the pain inflicted on errant members, individuals of a group will exert effort to bring back members who have strayed from group ideal behaviour back to the fold. The important point to note here is that the rebel group may use this type of behaviour, denoted in (5) above to solve the collective action problem, as described by Olson (1965). Thus, group grievances become individual grievances, and individuals act upon their group grievances. This, at the extreme, can include terrorist acts.

The rebel group, objective or utility function, $R$, takes the following form:

$R=\pi(a, e) R^{P}+(1-\pi)(\cdot) R^{C}-E(e, t)$

where:

$R^{P}=Y^{R}-p F^{R}(\mu)+T(A)$

$R^{C}=Y^{R}-c F^{R}(\mu, \theta)+\lambda T(A), F^{R}{ }_{\theta}, F_{\mu}{ }^{R}>0$

$e=\frac{T(A)}{\theta F^{R}(\mu)}$

$Y^{R}$ denotes rebel group or dissident group consumption, and $R^{P}$ and $R^{C}$ describe their budget constraints. The rebel group choice's surround $e$ (effort with regard to peace with the state), $E$ describes the cost function for undertaking $e$, composed of mainly psychic costs of 'capitulation', with $E_{e}>0 . F^{R}$ represents direct action against the state. ${ }^{11}$ Here $\theta$ denotes the dissidents group's historical hatreds and the lack of contemporary social standing.

\footnotetext{
${ }^{10}$ For example, following Stewart (2008) it can be pointed out that social surveys indicate that Muslims are disliked more in the Netherlands, compared to the UK.

${ }^{11}$ Note group behaviour with respect to $e$ has a different to individual, $e_{r}$
} 
Differentiating the dissident group's strategic variable $(e)$ we find:

$d e=\frac{T_{A}}{\theta F^{R}(\mu)} d A-\frac{T}{\theta^{2} F^{R}(\mu)} d \theta-\frac{T}{\theta F_{\mu}^{R 2}} d \mu$

The first term on the right-hand side of (8) is positive, $e$ rises with $T$, but falls with $\theta$ and $\mu$. In other words, transfers from the state raise peaceful behaviour; a loss in social standing, and government militancy, decrease peaceful behaviour by the rebels towards the state.

The dissident or rebel group will maximise (6) with respect to $e$ :

$\pi_{e}\left[R^{P}()-.R^{C}().\right]=E_{e}$

\subsection{Reaction functions}

In order to analyse variations in parameters we first need to obtain a set of reaction functions in $(a, e)$ and $(D, t)$ space to capture government-rebel and sponsor-terrorist interaction. Equations (4) and (9) form the basis of the reaction functions for the government and the rebels, obtained by totally differentiating them with respect to $a$ and $e$. Thus:

$\frac{d e}{d a / R^{G}}=\frac{C_{a a}+\pi_{a a}\left[G^{C}(\cdot)-G^{P}(\cdot)\right]}{\pi_{a e}\left[G^{P}(\cdot)-G^{C}(\cdot)\right]} \frac{\geq}{\leq}$ if $\pi_{a e} \frac{\geq}{\leq} 0$

and

$\frac{d e}{d a / R^{R}}=\frac{\pi_{a e}\left[R^{P}(\cdot)-R^{C}(\cdot)\right]}{E_{e e}+\pi_{e e}\left[R^{C}(\cdot)-R^{P}(\cdot)\right]} \stackrel{\geq}{\leq} 0$ if $\pi_{a e} \frac{\geq}{\leq} 0$

Note that $\pi_{a e}=\pi_{e a}$ by symmetry. Also even though $\pi_{a}, \pi_{e}>0, \pi_{a a}, \pi_{e e}<0$, meaning there are diminishing returns to peaceful behaviour. $C_{a a}, E_{e e}>0, R^{P}>R^{C}, G^{P}>G^{C}$.

We assume that the two strategies are complements, $\pi_{a e}>0$. In other words more peaceful action or warlike behaviour by one side leads to the same by the other. The reaction functions will be positively sloped in Figure 1.

\subsection{An increase in government militancy (a rise in $\mu$ ):}

An increase in government militancy (a rise in $\mu$ ) may result from an increase in the vote bank of populist political parties that are more confrontative, or an increase in the supply of repetitive hate-creating stories by politicians (Glaeser, 2005) culminating in laws banning head scarves, tighter immigration from certain countries and involuntary integrationist policies. In Figure 1 the reaction function of the government $R_{1}^{G}$ shifts leftwards to $R_{2}^{G}$, as there is less incentive to be peaceful $(a)$ for each level of $e$, see equations (1)-(3). A similar line of reasoning applies to the rebels, (see equations (6) and (7)), and the rebel reaction functions shift down from $R_{1}^{R}$ to $R_{2}^{R}$. The new 

and $e$, peaceful behaviour by both sides to this quarrel, but a greater decline in $a$ relative to $e$.

\section{Figure 1: Strategic Interaction Between the Government and Rebels}

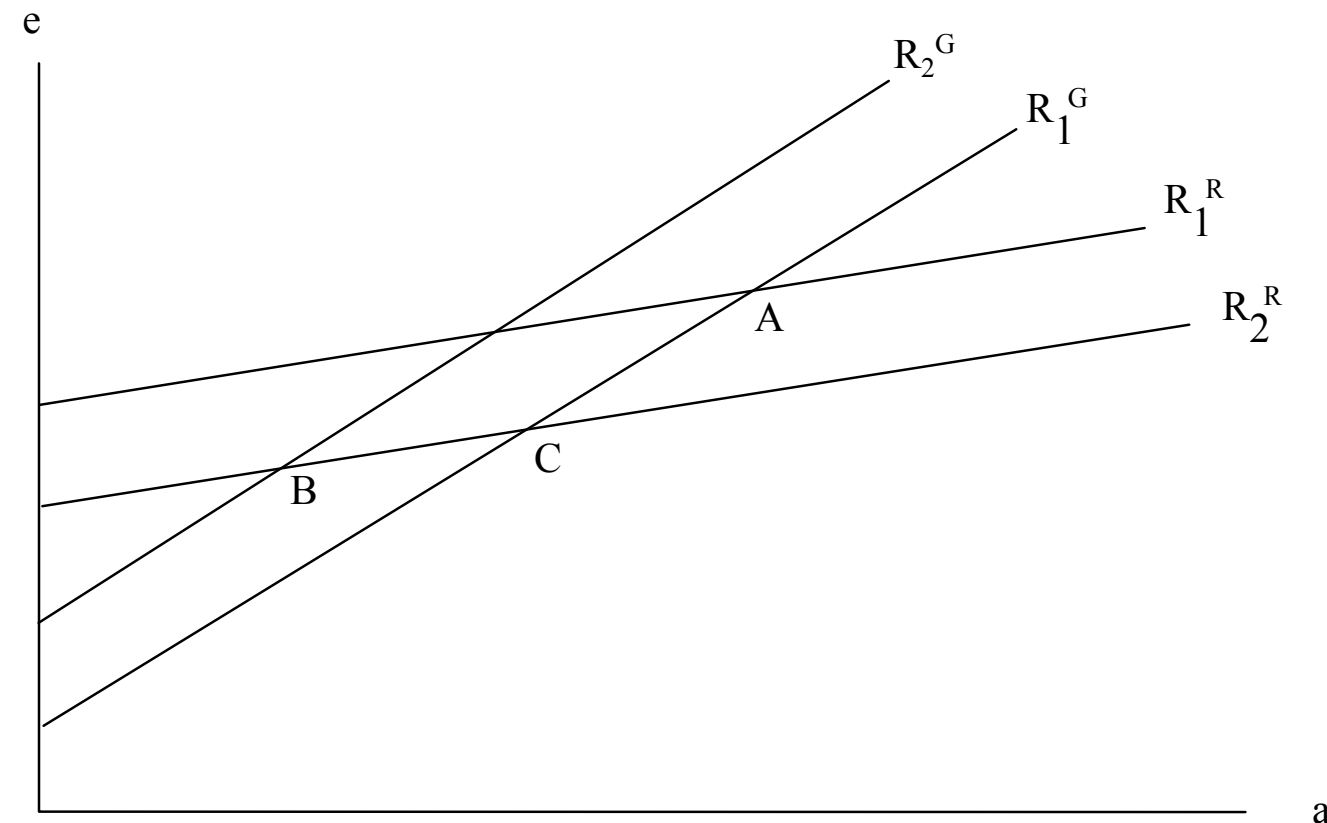

\subsection{A Rise in Rebel Intrinsic Motivation to Fight the State $(\theta)$}

A rise in the intrinsic motivation to fight the state by the dissidents can arise because of two sets of reasons. One is a loss in domestic social standing. This includes a perception of the widening of economic, political and social horizontal inequalities ${ }^{12}$ that discriminate against Muslims in European countries as discussed by Stewart (2008), or a gradual reaction to laws that discriminate against Muslims (such as head scarf bans initiated by the state). The second relates to world events, such as the invasion and occupation of Iraq and Afghanistan, and the situations in Palestine or Kashmir, that add to the collective Muslim stock of grievances. For example, the current Israeli military operations in Gaza, and the perceived Western support for this incursion, which many regard as a disproportionate reaction to Hamas' activities, can only serve to increase resentment among Muslims. Either way, the rebel reaction function will shift down in Figure 1 indicating less $e$, and more fighting against the state at point $\mathrm{C}$.

\section{TRANSNATIONAL CRIME}

\footnotetext{
${ }^{12}$ This includes higher job discrimination (unemployment) amongst Muslim youths, widely believed to have sparked off the riots in France in 2005.
} 

within a macroeconomic context. Imagine an economy that has two broad sectors, following Murshed (2005). Output in the criminal sector is an exportable for the South, consumed entirely in the North. Total output or aggregate supply in the South $\left(Y_{S}\right)$ can be said to be composed of production in two sectors: legal activities $(S)$ and criminal activities $(M)$ :

$$
Y_{S}=f(S, M) \quad f_{1}>0, f_{2}<0 .
$$

The reasoning behind the above is that criminal activities detract from total output as there are negative externalities involved; these include complicity in crime (bribery and coercion), law enforcement, and the negative spillover effects of foreign sponsored destruction of narcotic supply. The first two costs are akin to the directly unproductive profit seeking activities (DUP) mentioned in Bhagwati (1982). ${ }^{14}$ It should also be borne in mind that DUP actually reduces total output. A good example of the last point is the US government's DEA (Drug Enforcement Agency) sponsoring the destruction of coca plantations in Bolivia, Colombia and Peru. Although compensation is paid, there are bound to be negative effects from some of the processes used, such as the aerial spraying of coca crops. The same would be true in Afghanistan.

Equation (12) may be rewritten as a function of the two alternative instruments utilised to restrict $M$ :

$Y_{S}=f(S, M(t, v)) \cdots M_{1}<0, M_{2}>0$

Here $t$ indicates the ad-valorem consumption tax equivalent of a quota in the North, and $v$ stands for the tariff or tax equivalent of the quantitative export restraint in the South. I will refer to the former as the "tariff" and the latter as the "VER" (voluntary export restraint); see Murshed (1992a and 1992b) on their differences. Both the "tariff" and the VER are quantitative restrictions. The tariff is like a quota restriction on the demand side and the VER a quota type restraint in the supply side. This is because we are dealing with a contraband substance, which cannot be directly taxed, as it is illegal. But the restrictions will both have their certainty tax equivalents, which we utilise in the model in this paper. The crucial difference is that the tariff is a demand side restriction where the revenues are retained in the consuming region (North); whereas the VER is a supply side control where the monopoly rents generated are kept in the producing region (South). Therefore, the tariff has a negative impact on domestic value-added in the $\mathrm{C}$ sector, whereas the VER does not.

Consider the following mark-up pricing rule describing supply behaviour in the $M$ sector $^{15}$ :

$P_{M}=z W(1+x)$

\footnotetext{
${ }^{13}$ I employ the term 'South' to denote a narcotics supplying country or region in the developing world.

${ }^{14}$ DUP was the original longhand in the lexicon of economics for corruption. It also resonates with our present-day pre-occupation with the saliency of institutions in determining growth.

${ }^{15}$ There is a huge amount of value added between the primary commodity (the opium or coca plant's harvest) and the final valued added in terms of heroin or cocaine.
} 
Domestic Terrorism and International Crime

Syed Mansoob Murshed where $P_{M}$ indicates the price of the criminal product, $z$ is a labour-output coefficient (the inverse of labour productivity), $W$ is the wage rate, and $x$ indicates the profit extracted by the warlord or drug baron. Let us say a quantitative restriction is placed on the sale of drugs taking the form of a domestic supply restraint (VER). This will cause the price of $M$ to rise, and result in positive monopoly rents that are retained domestically. ${ }^{16}$ Note, that I have omitted capital, intermediate input and other costs of enforcement from (14), whose inclusion would only complicate the algebra, and enforcement costs already enter via the DUP activities captured in (12) above. If we assume that labour productivity $(z)$ and wages are $(W)$ are constant, then these rents will be captured by warlords:

$$
P_{M}(1+v)=z W(1+x)
$$

Differentiating the above with respect to $v$, for constant values of $z$ and $W$, we obtain:

$P_{M}+\frac{d P M}{d v}=z W \frac{d x}{d v}$

In the case of the tariff, it works on the demand side and the revenues are collected in the North. It, therefore, constitutes a leakage from the domestic sector, and the differentials in (16) with $t$ instead of $v$ need to be evaluated with a negative sign.

Utilising the information in (13) to (15), one may rewrite (13) as:

$Y_{S}=f\left(t P_{M}, v P_{M}\right) \ldots f_{1}>0, f_{2}<0$

Equation (17) is the short-run aggregate supply function for the economy in the South. The two arguments inside the function above represent tariff and VER revenues respectively. The former has a positive impact on aggregate supply in the South, as it is external, and actually diminishes DUP and other harmful externalities. It works on the demand side. Nationals of the South residing in the North could capture some of these tariff revenues. These monies could find their way back to the domestic economy via money "laundering". Laundering is a pure asset swap; it does not affect the total stock of assets in the economy, but merely converts illegally obtained money into an existing legally owned asset. By contrast, a VER is postulated to have negative supply-side effects. It is a domestic quantitative restriction, which is a method of restricting $M$ from the supply side. It impacts negatively on total output because of the negative externalities arising from crop eradication, corruption and law enforcement. In principle, however, it does augment domestic demand or expenditure. Some of this will be moderated by import leakage. Also, any positive aggregate demand effects hinge crucially on income distribution. If warlords, who capture, this rent have a low propensity to consume domestic goods then the aggregate demand effects will be negligible. It is also worth noting that unlike with a VER, an import tariff on $M$, which is collected in the North, will have little impact on the South's income distribution.

\section{Figure 2: Tariff versus a VER}

\footnotetext{
${ }^{16} \mathrm{I}$ am assuming that the demand for $M$ (for example addictive drugs) is highly inelastic.
} 


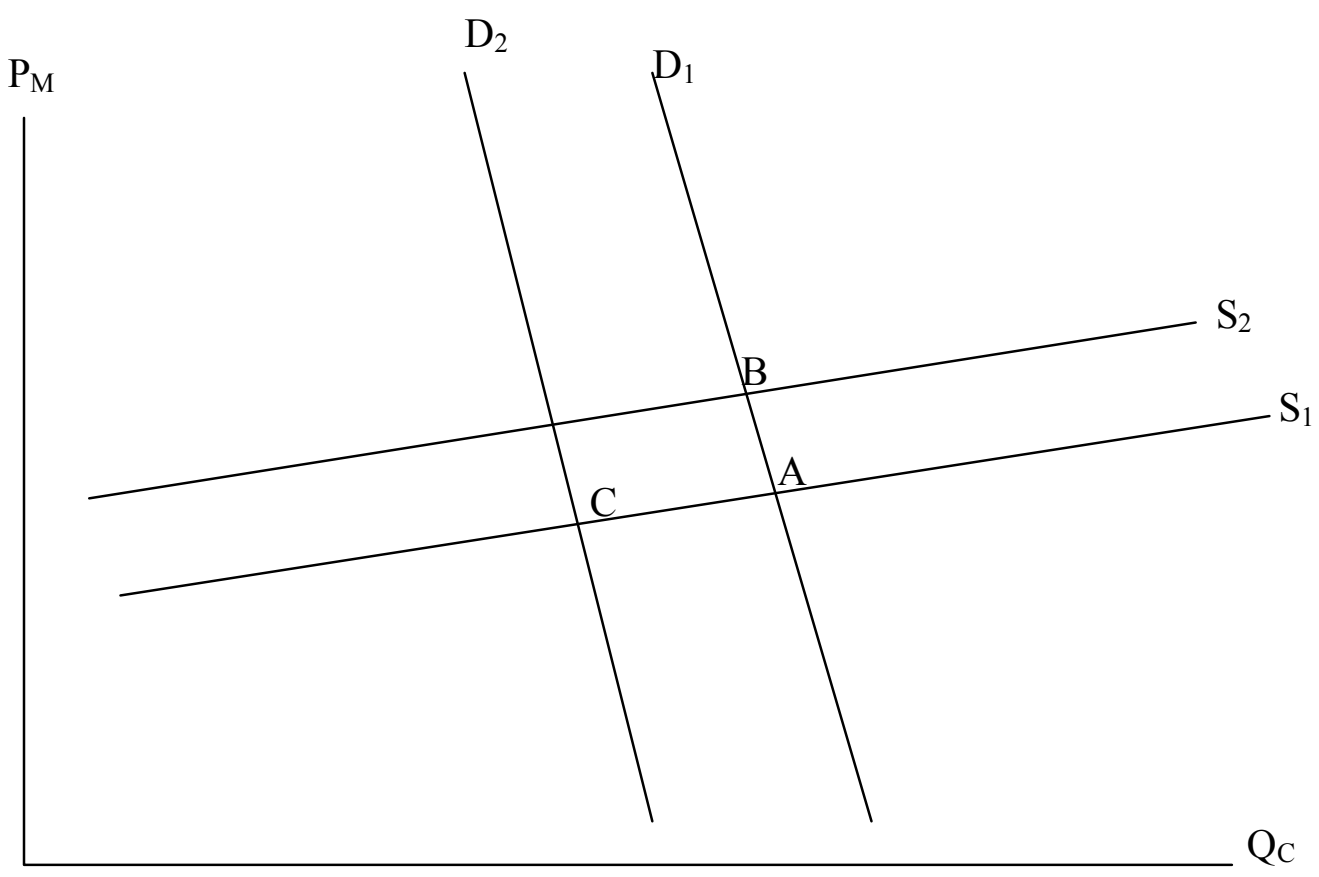

The analytical differences between a tariff and a VER can be understood by means of a demand-supply diagram for narcotics, as in figure 2. The demand and supply schedules are labelled D and S respectively, with the quantity of narcotics depicted on the horizontal axis, and the price in the vertical axis. We start from an initial equilibrium at point A on the diagram. A VER reduces supply, the supply curve shifts from $S_{1}$ to $S_{2}$. At point $B$ in the figure the world price of narcotics has risen. In the supplying region, the South, there is a negative aggregate supply effect and income is redistributed towards warlords and drug barons. Equilibrium aggregate output and national income may decline in the South. A tariff or its quota equivalent, however, eventually lowers the demand for narcotics. The demand schedule shifts leftwards to $\mathrm{D}_{2}$. At point $\mathrm{C}$, the world price for narcotics (not the domestic tariff-ridden price in the North) has gone down. There are no negative aggregate supply-side effects in the South, and there are possible increases in national income in both regions. Thus the tariff or its quota equivalent may be a superior mode of intervention to control narcotics, compared to a VER.

Following the results in Murshed (2005), a tariff-equivalent is the first-best mode of control for the socially undesirable $M$ good consumed in the North and produced in the South. It has a direct impact on demand. It could also increase income in both regions. It has a positive supply side effect in the South and does not have the unfavourable income distribution effects of domestic supply controls. The VER is, by contrast, a control mechanism working on the supply side of the $M$ sector in the South. It creates undesirable rents that go to warlords (who may be helping the USA in the war on terror, but not drug eradication), lowers aggregate supply via negative externalities as well as DUP, and leads to unfavourable alterations in income distribution that further disadvantages the drug producing farm household. It could also diminish equilibrium output in both regions. When a supply restraint is accompanied by a policy of aid, this could benefit the donor (North) at the expense of 

of 'wasted' aid on Afghanistan (Ghani and Lockhart, 2008). This is likely to be the case when the aid that accompanies the destruction of coca or opium crops mainly goes to the military and results in imported security expenditure. The crucial hypothesis behind the results in the model rest with the nature of the aggregate supply effects of the two output restraining instruments, as well as the aggregate demand effects of aid.

The observant reader will have realised that the policy superiority of the tariff or tax equivalent on consumption will increase if the illegality of drugs in the consuming region is removed. But that is the point behind the dominance of a tax over a quantitative restriction or prohibition. The former implies forcing consumers to pay more for something that they are allowed to use. The latter is a regulation, which creates the necessity for evasion, extortion and other shadowy underground activities. Revenues from a tax can be better utilised in preventive and rehabilitation programmes. In the producing region, legality will help eliminate the wasteful DUP type activities that lower total output. It would also make it possible for the state to extract some of the monopoly rents associated with production, which can then be used for fiscal stabilisation and poverty alleviation.

Even if drugs continue to be illegal, a far superior policy-mix would include the taxation equivalent on the demand side of the problem. On the supply side it would be better to tackle the causes of increased drug production directly rather than simply destroy crops and arm governments. The causes include internal conflict, falling commodity prices, and state failure in social provisioning. Aid, which only goes to the military and not for broad-based poverty alleviation could ultimately have disastrous consequences, as it will intensify existing civil wars. The rise in poverty, as well as the poverty-conflict nexus, is perhaps the greatest cause of increased drug production at the primary stage.

\section{CONCLUSIONS}

I would like to conclude by first arguing that Islamic fundamentalism feeds on the West's historical and present rejection of Islam in its struggle to achieve parity as an equally important world religion, as well as the present-day objective, and perceived, maltreatment of Muslims and Muslim causes. I do not believe its distaste for the West is based on primordial hatred; nor is the primary 'fundamentalist' objective the obliteration of Western values ${ }^{17}$; the removal of objective injustices, glaring doublestandards when it comes to the Muslim world, and of course economic progress will take the wind out of the sails of fundamentalism. One of the enduring lessons of history is that economic development and prosperity modifies culture, religious beliefs and practices.

As far as the policy implications are concerned, first excessive deterrence against potential terrorists may backfire, a point also made by Frey and Lüchinger (2004).

\footnotetext{
${ }^{17}$ As stated, for example, by the former British Prime Minister Tony Blair in an address at Georgetown University, Washington D.C, on $26^{\text {th }}$ May 2006.
} 
Domestic Terrorism and International Crime

Syed Mansoob Murshed Secondly, space needs to be created so that most Muslim migrants are able to merge their personal identities within their adopted European homelands. In other words, policies that make it difficult to be both European and Muslim are bound to be selfdefeating, and voice needs to be given to a wider range of Muslims, not just the Salman Rushdies and Hirsi Ayan Alis of Europe. Thirdly, the economic discrimination, Muslim horizontal inequalities in Europe need addressing. Fourthly, demand side regulation of illegal substances needs to be pursued. Finally, aid to fragile states needs to be broad-based and poverty reducing, not just benefiting warlords and drug barons.

\section{REFERENCES}

Addison Tony and S. Mansoob Murshed (2005) 'Transnational Terrorism as a Spillover of Domestic Disputes in Other Countries', Defence and Peace Economics, 16 (2): 69-82.

Akerlof, George and Rachel E. Kranton (2000) 'Economics and Identity', Quarterly Journal of Economics, 115(3): 715-753.

Bhagwati, Jagdish (1982) 'Directly-Unproductive Profit-Seeking (DUP) Activities', Journal of Political Economy, 90: 988-1002

Chossudovsky, Michael (2002) 'Hidden Agenda behind the "War on Terrorism": US Bombing of Afghanistan restores Trade in Narcotics', http://globalresearch.ca/articles/CH0205B.html

Frey, Bruno and Simon Lüchinger (2004) 'Decentralization as a DisIncentive for Terror', European Journal of Political Economy, 20(2): 509-15.

Gates, Scott (2002) 'Recruitment and Allegiance: The Microfoundations of Rebellion', Journal of Conflict Resolution, 46(1): 111-30.

Ghani, Ashraf and Clare Lockhart (2008) Fixing Failed States, Oxford: University Press.

Glaeser, Edward L (2005) 'The Political Economy of Hatred', Quarterly Journal of Economics, 120 (1):45-86.

Hirshleifer, Jack (1995) 'Anarchy and its Breakdown', Journal of Political Economy, 103(1): 26-52.

Huntington, Samuel P (1996) The Clash of Civilizations and the Remaking of the World Order, New York: Simon and Schuster.

Lindner, Evelin G (2001) The Concept of Humiliation: Its Universal Core and Culture-Dependent Periphery, University of Oslo. 
Murshed, S Mansoob (1992b) 'Commercial and Monetary Policy in a North-South Macroeconomic Model: Tariffs and VERs Compared', Australian Economic Papers, 31, 414-26.

Murshed, S. Mansoob (2002) 'Conflict, Civil War and Underdevelopment', Journal of Peace Research, 39 (4): 387-93.

Murshed, S. Mansoob (2005) 'Quantitative Restrictions on the Flow of Narcotics: Supply and Demand Restraints in a North-South Macro-Model, Defence and Peace Economics, 16 (5): 391-401.

Olson, Mancur (1965) The Logic of Collective Action, Cambridge MA: Harvard University Press.

Stewart, Frances (2000) 'Crisis Prevention: Tackling Horizontal Inequalities', Oxford Development Studies, 28(3), 245-62.

Stewart, Frances (2008) 'Global Aspects and Implications of Horizontal Inequalities (HIs): Inequalities Experienced by Muslims Worldwide’, mimeo.

UNDCP (1998) 'Statistics and Analysis on Supply of and Trafficking in Narcotic Drugs and Psychotropic Substances-1996', Vienna: United Nations Drug Control Programme.

Wintrobe, Ronald (2002) 'Can Suicide Bombers Be Rational', Paper prepared for the DIW Workshop on Economic Consequences of Global Terrorism, www.diw.de. 